\title{
鳴瀬川河口部における砂州地形変化機構 STUDY ON MECHANISM OF SAND BAR INTRUSION AT THE NARUSE RIVER MOUTH
}

\author{
川村 育男 1 ・田中 仁 2 \\ Ikuo KAWAMURA, Hitoshi TANAKA \\ 1正会員 工博 株式会社建設技術研究所（９９０-0014 仙台市青葉区本町 2-15-1)
27 エロー 工博 東北大学大学院工学研究科土木工学専攻（９９80-8579 仙台市青葉区荒巻字青葉 06)
}

The Naruse River mouth showed stable topography at least until 1996. However, sand bar on the left-hand side of the river mouth has been declining in recent years. The behavior of the morphology of the river mouth after the flushing of the sand bar has never been observed. In this paper, characteristic morphological change at the Naruse River mouth is shown with the use of aerial photographs and morphological maps. In order to determine the main factor of morphological change, numerical simulation of extended Boussinesq equations are applied. It is concluded that, the mechanism of the sand bar intrusion into the river is explained by wave overtopping over the left-hand side sand bar at the river mouth. Furthermore, sand bar height and width are important factors of sand bar intrusion.

Key Words : Naruse River, sand bar decline, sand bar intrusion, Extended Boussinesq equations, wave overtopping

\section{1.はじめに}

河口部の地形は, 波浪 , 潮汐流 , 河川流等の樣々な外 力を受けるため非常に複杂隹な変化を示す. 適度に発達し た河口砂州は塩水や波浪の進入を防ぐ効果を持つが，極 端な河口閉塞は洪水時に流下能力の低下をもたらし治水 上望ましいものではない．

本稿て対象とする一級河川・鳴瀬川河口には二本の導 流堤があり，昭和30年頃から近年に至るまで, 長期にわ たり安定した河口砂州形状を維持してきた．しかし，近 年河口部左岸側の砂州は後退して来ており，平成14年7 月の出水によりフラッシュされた . 兴の後この砂州は, 元の安定した形状に回復することなく河道内に侵入する といった，これまで見られなかった挙動を示している。 砂州が河道内に侵入することにより, 河口港への航路障 害等の問題か生じたばかりでなく, 砂州による河積阻害 が洪水時の河道水位上昇へ与える影響も懸念されている． 導流堤のある河口において砂州力後退し, 河道内に侵入 する現象は他河川でも確認されており (川村ら ${ }^{1)}$ ) ，こ のような一連の砂州の挙動機構を明らかにすることは, 適切な河口維持管理のために重要である.

本研究では, 鳴瀬川河口部を対象にシミュレーション を行い, 砂州の河道内侵入現象の要因について考察する

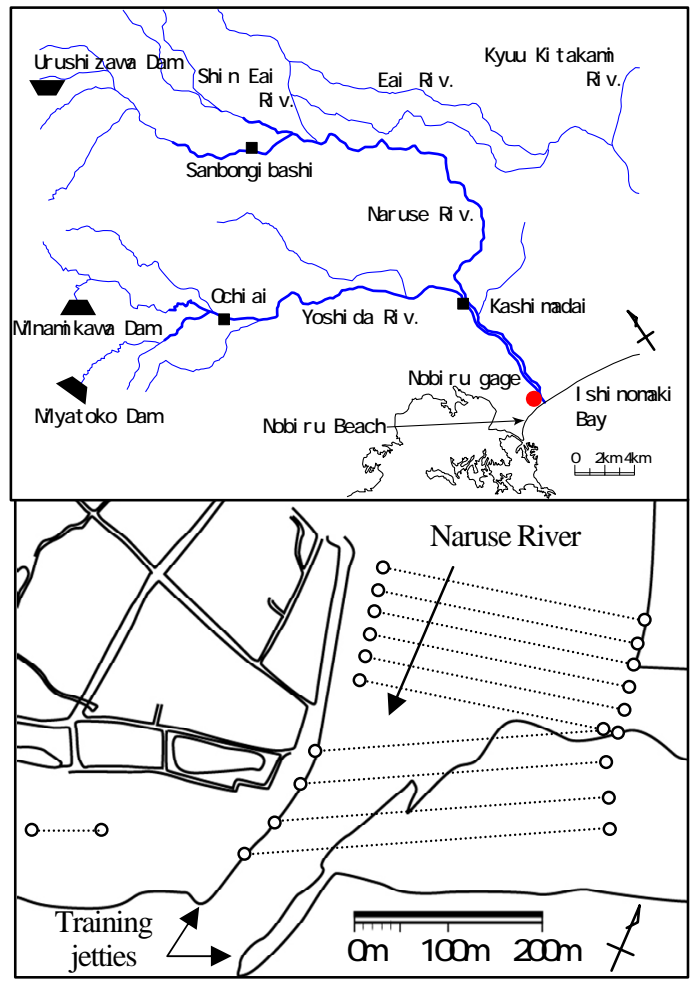

図-1 鳴瀬川河口の位置

とともに, 砂州形状力砂州の河道内侵入現象に与える影 響について検討した 。 


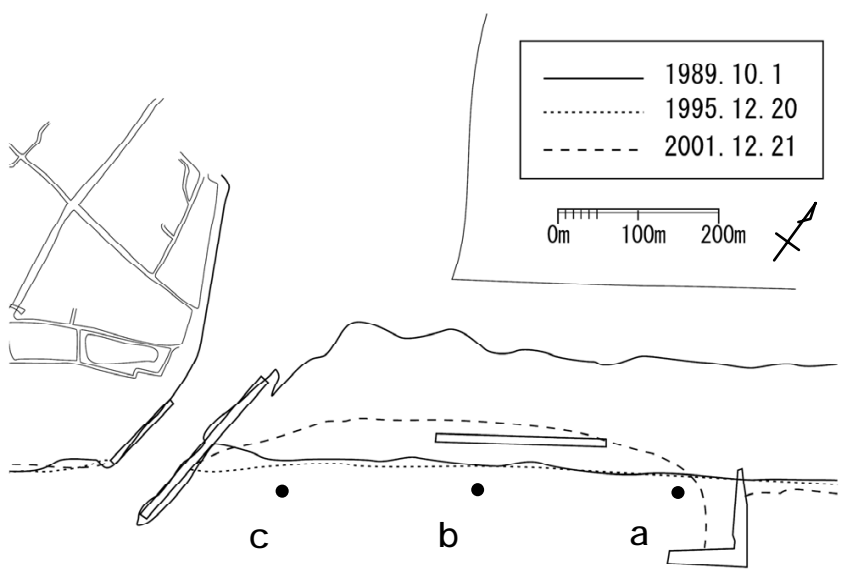

図- 2 鳴瀬川河口部汀線

\section{2. 鳴瀬川の概要}

図-1に鳴瀬川河口の位置図を示す．鳴瀬川は宮城・山 形県境の船形山を源とし，鹿島台町より吉田川と併流の のち, 河口付近で合流し石巻湾に注ぐ幹川流路延長 $89 \mathrm{~km}$ ，流域面積1,133km²の一級河川である . 河口から約 $0.5 \mathrm{~km}$ 上流に野蒜水位観測所があり，石巻湾東端に位置 する牡鹿半島に鮎川検潮所がある。また，河口には，明 治初期の大規模港湾計画「野蒜築港」以来の歴史的建造 物である導流堤がある.

近年におけるイベントを河川流域と沿岸域に分けて整 理すると，河川流域では鳴瀬中流㘿か2002年に完成して おり，桑折江堰の建設が1998年から行われている．また， 支川吉田川において宮床多が1998年に竣工している． 一方 , 沿岸域では鳴瀬川河口から石巻港に至る大曲海岸 の侵食対策として1990年から2000年にかけてヘッドラン ドか8基設置されている $\left(\right.$ 佐藤ら $\left.{ }^{2)}\right)$ 。

\section{3 . 河口部の地形変化と波浪場への影響}

\section{(1) 近年の地形変化}

図-2は，1989年10月，1995年12月及び2001年12月にお ける汀線である . 1989年の汀線は空中写真 , 1995年およ び2001年の汀線は宮城県石巻港湾事務所により行われた 深浅測量を基にしている.1995年12月以降, 左岸側の砂 州がせ細り，汀線か後退している樣子か確認できる。 左岸導流堤の東側 (図右方向) に見られる鍵状の構造物 がッドランドであり，1996年から1998年に暫定形状

(ヘッド部なし) か施工され (佐藤ら ${ }^{2)}$ ) ，光の後2000 年までにヘッド部か施工された .

また , 図一に図-2に示した3地点 $(a, b, c)$ におけ る地盤高の経年変化図を示す .ここで, 地盤高の基準高 S.P.0.0m=T.P.0.0m-0.0873m（T.P.は東京湾中等潮位）で ある . a地点における地盤高は概ね $1 \mathrm{~m}$ 程度の幅て変動し

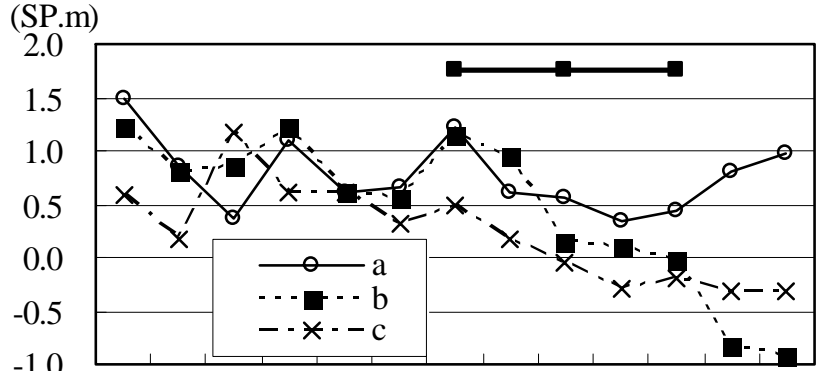

'90 '91 '92 '93 '94 '95 '96 '97 '98 '99 '00 '01 '02 図-3 地盤高の経年变化

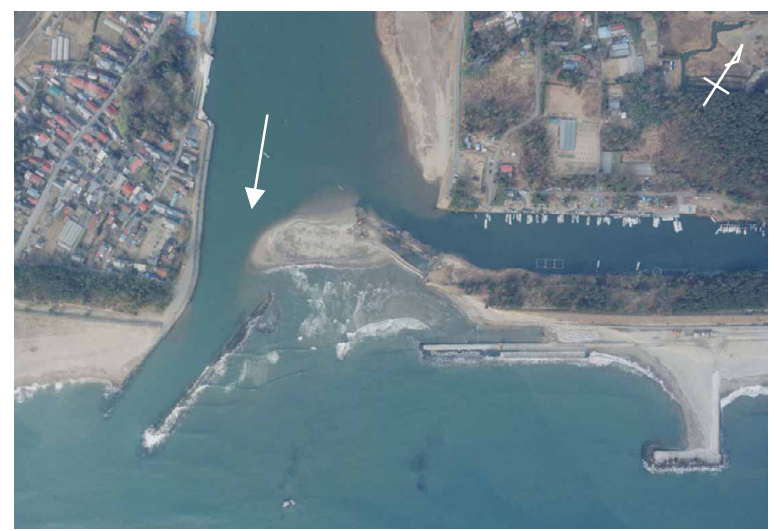

写真- 1 鳴瀬川河口 (2002年12月18日)

ているが, 1997年からの減少傾向は2000年のヘッドラン ド完成後は回復傾向にある . 一方, b地点及びc地点にお いては，1997年以降，地盤高力低下傾向 (侵食) にある. 石巻湾における沿岸漂砂の卓越方向は南西向き (図-2左 向き) であることから (望月ら $\left.{ }^{3)}\right)$ ，ヘッドランドによ り沿岸漂砂の供給か制限されたことか侵食の主な要因で あると考えられる .

このように近年砂州の浸食が進行しているなか , 2002 年7月11日の出水により, 導流堤左岸側の砂州はフラッ シュされた . フラッシュされた砂州は元の安定形状に回 復することなく写真-1に示すように河道内に侵入する挙 動を示している．なお，近年における最も大きな゙洪水の 一つである1986年8月洪水ではフラッシュされた砂州は 数ヶ月で元の安定形状に回復していた .

\section{(2) 波浪計算}

地盤高の変化が波浪場に与える影響を調べるため, 侵 食力始まる前の1996年と2002年の地形における波高を数 值シミュレーションにより算定した . 浅海域における波 浪計算には, 浅水変形や屈折, 反射などの波浪変形が表 現可能なブシネスク方程式が広く用いられている.ここ ではWeiら ${ }^{4}$ か $\mathrm{Nwogu}^{5}$ のモデルに高次精度の差分スキー ムを適用して浅瀬上ての波高解析により光の有効性を検 証し, 高次の非線形項を含む形へと発展させた「拡張型 の強非線形ブシネスクモデル(FUNWAVE)」を用いた . 


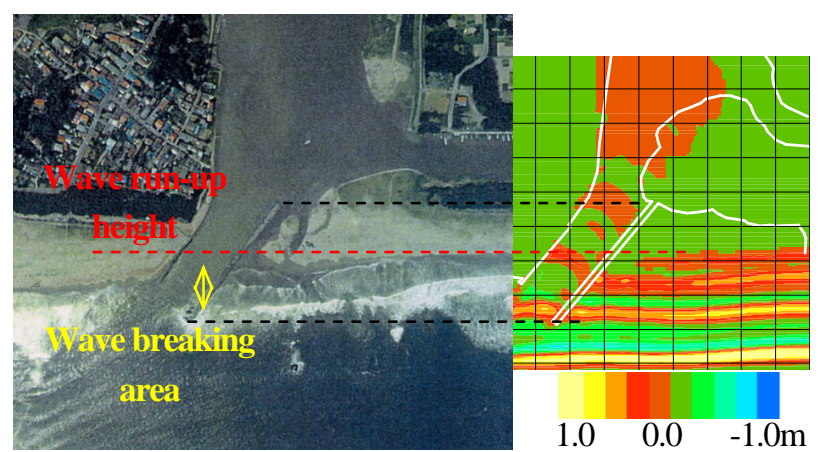

図-4 遡上高および砕波位置

このモデルを鳴瀬川河口部に適用したところ遡上高や砕 波位置などの再現性か確忍された .

計算領域の両側にはエネルギ一減衰帯を設け，両側境 界位置て無反射条件とした。また，計算格子間塥は $\Delta x=\Delta y=5 \mathrm{~m} （$ 格子数 $90 \times 200 ）$ とした .

図-4に1986年8月出水時における波浪条件て計算した 場合の波高分布と光のときの空中写真を示す . シミュ レーションでは導流堤の先端付近で妿波により水位か低 下しており，空中写真においてもこの付近で砕波か泩じ ている樣子がうかがえる.また, 遡上高さにおいても概 ね再現できている.

\section{(2) 砂州前面の水位差}

2002年地形と1996年の2ケースの地形を対象にシミュ レーションを行った . 入射波の条件はどちらのケースも 2002年7月の砂州フラッシュ後における最大遡上高発生 時の条件である波高1.62m，周期13.2sとした .

図-5に2002年地形での計算水位から1996年地形での計 算水位を減じた水位差分布を示す . 水位差はメッシュご との最高水位の差であり，砂州上の水位差は表示してい ない . 図中の赤いエリアが1996年に比べ水位が高くなっ ている箇所であり，砂州の前面で $0.5 \mathrm{~m}$ 程度の水位上昇が 見られる . 近年の砂州の侵食により海底地盤高が低下す ることによって, 砂州前面の波高か高くなったものと考 えられる .

\section{4. 地形変化シミュレーション}

\section{(1) 計算方法}

上述のシミュレーションモデルにより算出した底面流 速から漂砂量を算出し地形変化シミュレーションを行っ た . 河口部周辺は定常流成分と振動成分の共存場である ことから，弚れ光れの成分に分解して評価を行った。振 動成分については時々刻々変化する流速に対してせん断 応力を算出し，これらを総計し1周期あたりの正味の漂 砂量を算出した . 炎の後, 砂の連続式を用いて水深変化 量を算出し，波の作用時間を乗じて土砂移動量を算出し た。

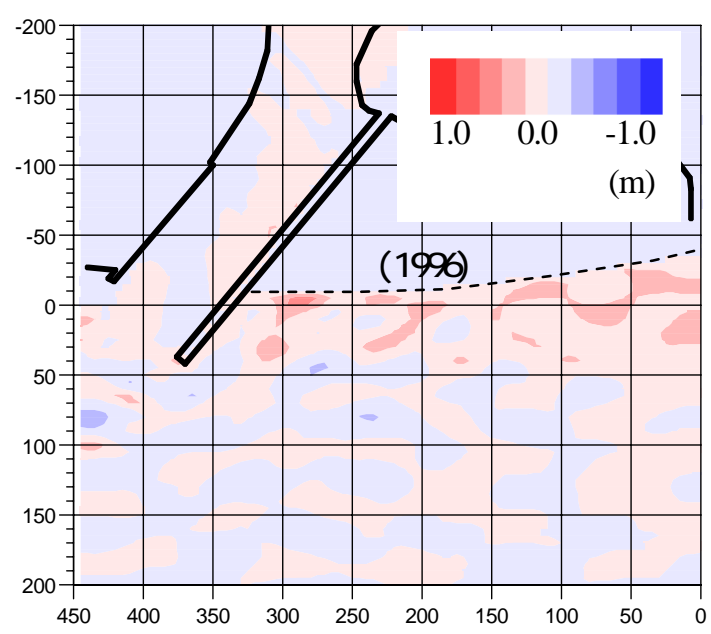

図 5 水位差分布

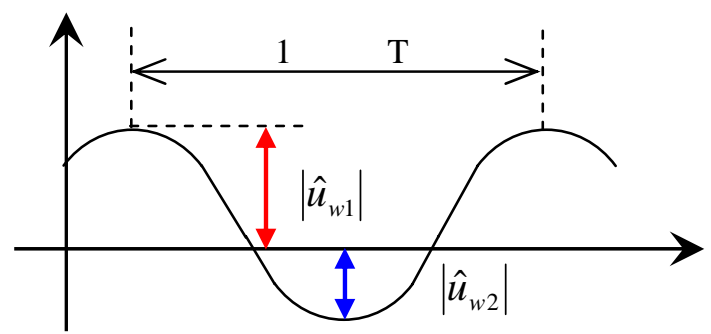

図 6 波動成分の振幅

定常流成分と振動流成分の共存場におけるせん断応力 は, 各々のせん断応力成分をべクトル的に合成した(1)式 で算定した $\left(\right.$ 南ら $\left.^{6}\right)$ ) . また , 合成せん断応力の方向は (2)式のようになる .

$$
\begin{gathered}
\tau^{2}=\tau^{2}{ }_{c}+\tau^{2}{ }_{w}+2 \tau_{c} \tau_{w} \cos \phi^{\prime} \\
\tan \Theta=\frac{\tau_{c y}+\tau_{w y}}{\tau_{c x}+\tau_{w x}}
\end{gathered}
$$

ここで, 添え字はは定常流成分でありwは振動流成分を 表し, $\phi^{\prime}$ は平均流速ベクトルと時々刻々の振動流流速べ

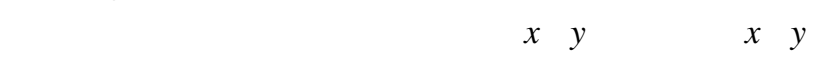
方向の成分を表す . 共存場における弚れ光れの成分のせ ん断応力(田中ら ${ }^{7,8)}$ を参考として以下の樣にして算出し た。

$$
\begin{gathered}
\tau_{c}=\rho \frac{\kappa^{2}}{\left\{\ln \left(z_{h} / z_{o}\right)-1\right\}^{2}} u_{c}^{2} \frac{\hat{u}_{c w}{ }^{*}}{u_{c}{ }^{*}} \\
=\frac{\kappa u_{c} \hat{u}_{c w}{ }^{*}}{\ln \left(z_{h} / z_{o}\right)-1} \\
\hat{\tau}_{w}=\rho \hat{u}_{w}{ }^{2}=\frac{\rho}{2} \exp \left\{-7.33+8.07\left(\frac{\hat{u}_{w}}{\sigma z_{o}}\right)^{-0.100}\right\} \hat{u}_{w}{ }^{2} \frac{\hat{u}_{c w}{ }^{*}}{\hat{u}_{w}{ }^{*}}
\end{gathered}
$$



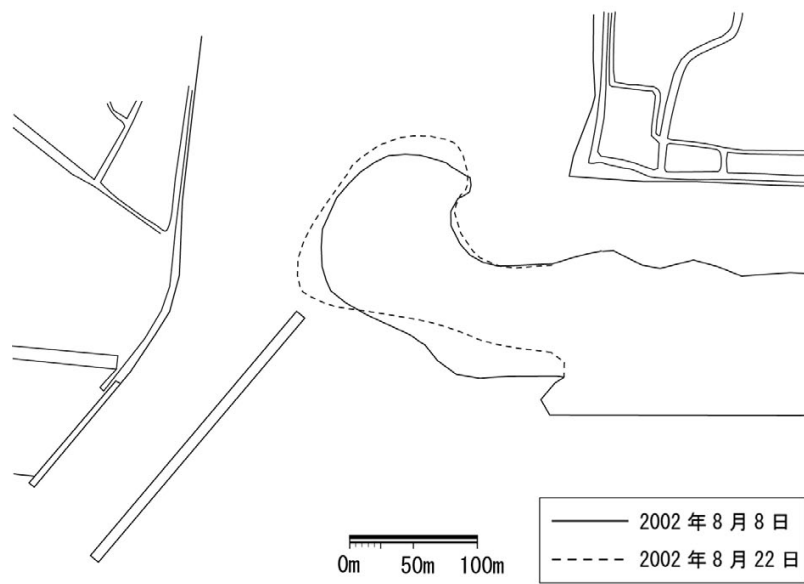

図-7 汀線図

$$
\begin{gathered}
\hat{u}_{w}{ }^{*}=\left[\frac{1}{2} \exp \left\{-7.33+8.07\left(\frac{\hat{u}_{w}}{\sigma z_{o}}\right)^{-0.100}\right\} \hat{u}_{w}{ }^{2} \hat{u}_{c w}{ }^{*}\right]^{\frac{1}{3}} \\
\vec{\tau}_{w}(t)=\frac{\vec{u}_{w}(t)}{\hat{u}_{w}} \hat{\tau}_{w} \\
\hat{u}_{w}=\frac{1}{2}\left(\left|\hat{u}_{w 1}\right|+\left|\hat{u}_{w 2}\right|\right)
\end{gathered}
$$

ここで, $\mathrm{n}(=0.4)$ はカルマン定数, $\mathrm{z}_{h}$ は水深, $\mathrm{z}_{0}=k_{s} / 30$ は 粗度高さ, $k_{s}$ は二クラーゼの相当粗度 , $\sigma$ は波動の角周 波数であり， $u_{w}{ }^{*}, u_{c w}{ }^{*}$ は乥れ光れ振動流成分および共存 場の摩察速度である . また, 上矩印はべクトル量を表し， 上ハットマークは振幅を表す. 式(7)に示した振動流流速 成分の振幅は峰振幅と谷振幅の平均を用いた（図-6)。 時々刻々の漂砂量は, (1)式で算出したせん断応力を Einstein and Brownの公式にあてはめ算出した . この漂砂 量は実質の漂砂量であるため, 土砂の連続式を解く際に は空隙率を考慮する必要がある.また, 実地形の地形勾 配や安息角を考慮するため, 土砂の連続式は(8)式の樣に した.ここで， $z_{b}$ は地盤高， $q_{x}, q_{y}$ は光れ光れ $x$ 方向,$y$ 方 向の実質の漂砂量を表す．また，入は空隙率を表し $\varepsilon_{s} は$ 正の值を持つ補正係数であり，ここでは $\lambda=0.4, \varepsilon_{s}=0.2$ と した。

$$
\frac{\partial z_{b}}{\partial t}=-\frac{1}{1-\lambda}\left\{\frac{\partial}{\partial x}\left(q_{x}-\varepsilon_{s}\left|q_{x}\right| \frac{\partial z_{b}}{\partial x}\right)+\frac{\partial}{\partial y}\left(q_{y}-\varepsilon_{s}\left|q_{y}\right| \frac{\partial z_{b}}{\partial y}\right)\right\}
$$

\section{（2）シミュレーション結果}

2002年7月の出水後約1ヶ月毎に河口部の汀線測量と横 断測量が行われている.測線は図一1に示した通りである .

図-7に2002年8月8日と8月22日における汀線を示す． 砂州が河道内に $20 \mathrm{~m}$ 程度侵入している樣子が分かる .こ
表-1 土砂堆積量

\begin{tabular}{|c|c|}
\hline 計算値 $\left(m^{3}\right)$ & 実測值 $\left(m^{3}\right)$ \\
\hline 8,700 & 8,200 \\
\hline
\end{tabular}

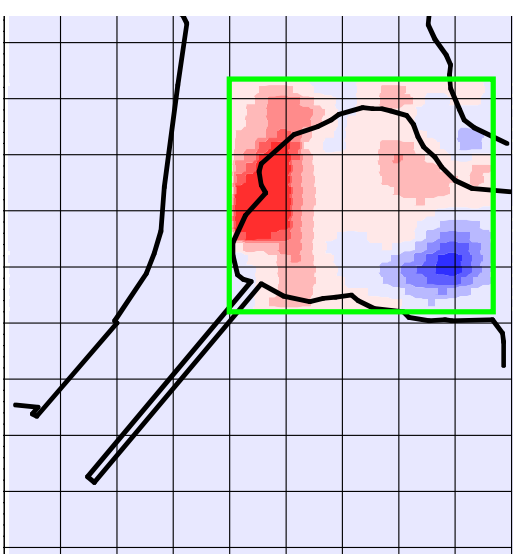

(m)

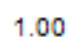

0.75

0.50

0.25

0.00

$-0.25$

$-0.50$

$-0.75$

$-1.00$

図-8 地盤高変化量 (実測値)

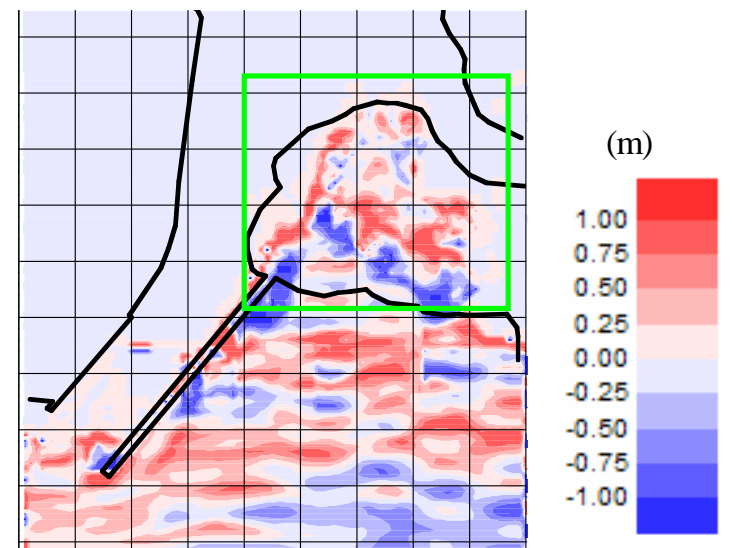

図-9 地盤高変化量 (計算值)

の期間における土砂堆積量の変化量を図-8に示す. 図中 の赤エリアか滩積箇所で青エリアが侵食箇所である . 図 中の囲み範囲における土砂堆積量は概ね28,200 $\mathrm{m}^{3}$ である .

図-9にこの期間を対象にして地形変化シミュレーショ ンを行った結果を示す.土砂堆積量の実測值を計測した 範囲における土砂堆積量は8,700m ${ }^{3}$ となった .

シミュレーションでは波浪のみを外力としており，鳴 瀬川河口部周辺で卓越している南西向きの沿岸流 (図-8, 図-9左向き) の影響は考慮されていない，実測值では砂 州西側に堆積箇所が集中し，地盤高が全体的にならされ ているのに対し, シミュレーションでは堆積, 浸食箇所 が分散して見られるのはこのためであると考えられる . ただし , シミュレーションにより算定した河道内の土砂 堆積量は，良く実測值を再現していると言える (表-1)， また, 地盤高の変化分布についても, 砂州前面の東側

(図中右側) において侵食力泩じ，導流堤と砂州の間や 砂州の裏側 (河道内) に堆積が見られるなど，概ねの傾 向はとらえられていると言える 

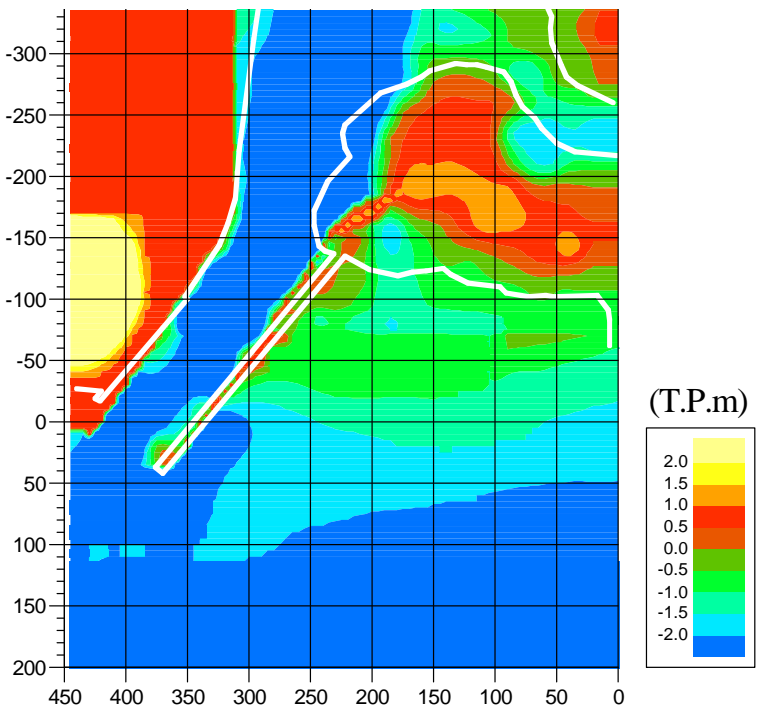

図-10 砂州地盤高（ケース1）

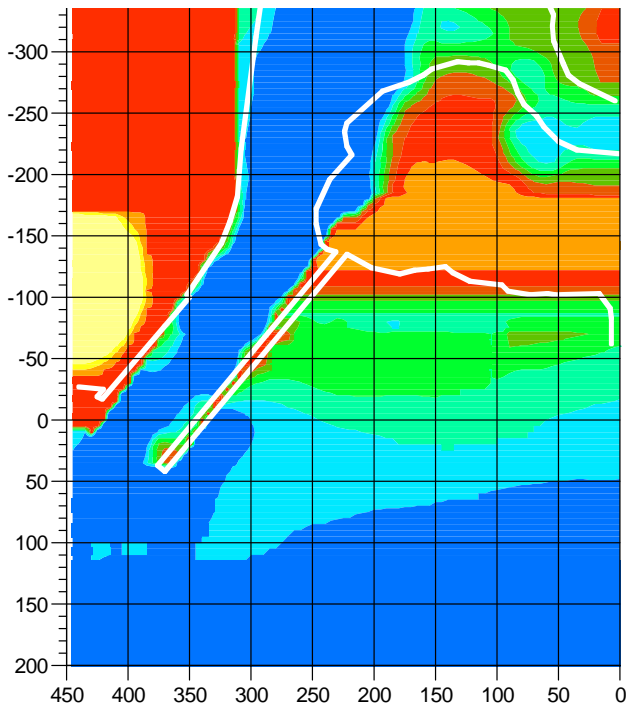

図-11 砂州地盤高（ケース2）

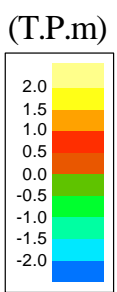

河道内に堆積していた砂州の中央粒径が0.3mmであり， 汀線付近の粒径とほぼ同じであったことや，この期間に は河川からの出水が無かったことを考慮すると，この砂 州の河道内侵入は主に波浪によりもたらされたものであ ると考えることができる . また , このシミュレーション モデルにより波浪による砂州の移動現象を再現すること ができた .

\section{5 ．砂州形状か砂州の河道内侵入に及ぼす影響}

砂州形状力砂州の河道内侵入に及ぼす影響を調へるたた めに，2002年7月出水によりフラッシュされた砂州形状 を基本にして2種類の砂州形状を想定して計算を行った . 波浪条件は2002年7月のフラッシュ以降で最も波の遡 上高が大きくなった時の条件である波高 $1.62 \mathrm{~m}$, 周期 13.2s , 潮位S.P.+0.76mとした . また , 計算時間はフラッ シュ以降において計算遡上高力砂州高を連続して上回る

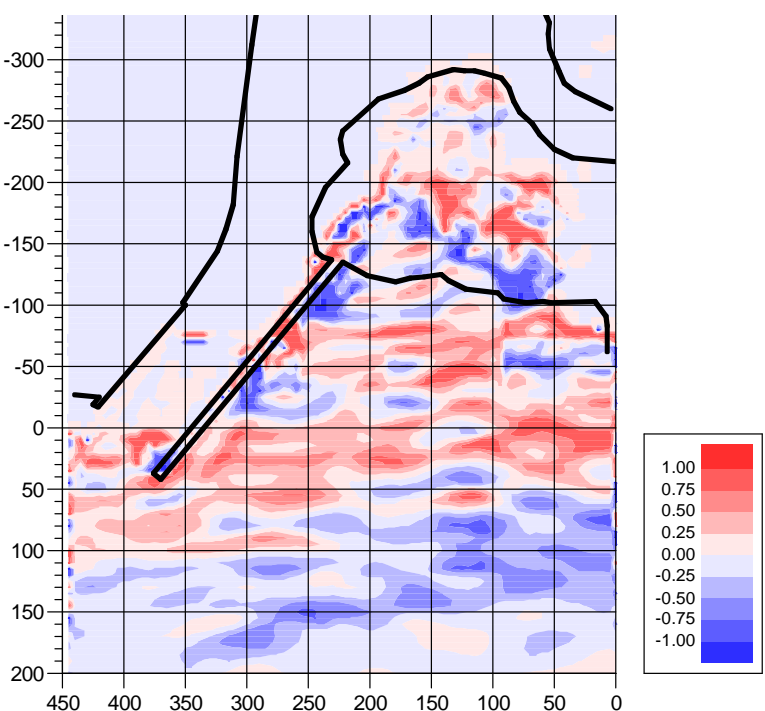

図-12 砂州地盤高 (ケース1)

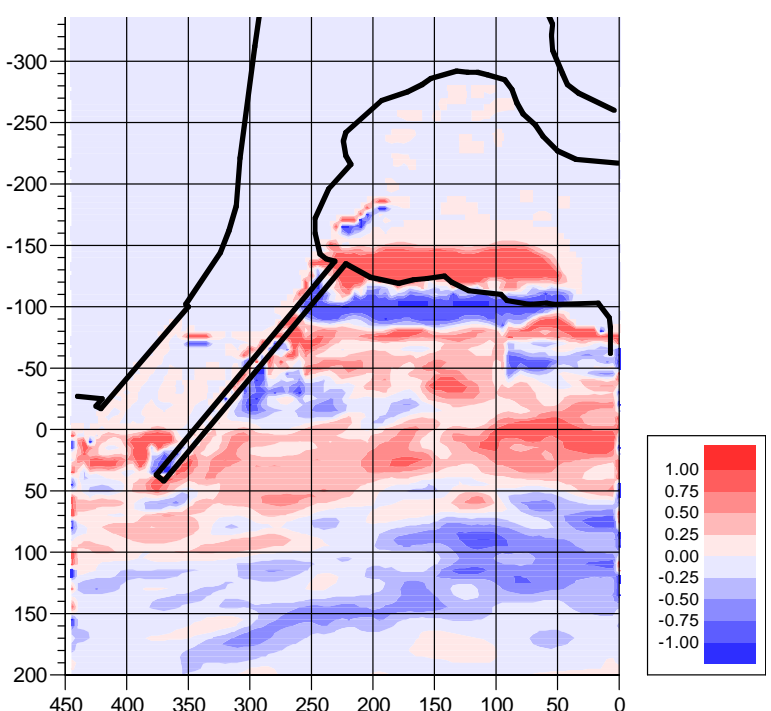

図-13 砂州地盤高（ケース2）

最長期間である18時間とした .

ケース1ではフラッシュにより形成された砂州と導流堤

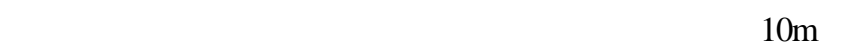
高さT.P.+1.4mの砂州を形成した . この高さは, フラッ シュ後の砂州の最高值である .ケース2では, 高さは同 樣にT.P.+1.4mとしたが , 砂州の天端副をフラッシュ前 の天端副相当の50mとした . 図-10, 図-11に乥れ光れの ケースの砂州形状を示す．

図-12, 図-13に光れ光れケース1, ケース2における砂 州地形を対象に地形変化シミュレーションを行った結果 を示す .ケース1では河道内に土砂か堆積し，砂州の河 道内侵入が見られる.一方 , ケース2では砂州の上部に 土砂滩積しているものの，河道内における土砂堆積は ほとんど見られない．このように砂州の形状によって砂 州の河道内侵入量の程度は異なり，所定の幅を持つ砂州 を形成することにより越波による砂州の河道内侵入を防 ぐことができる.なお，ケース 1 ，ケース 2 ケに導流堤 内に堆積が見られるが，これは河川流量による土砂移動 
を考慮してないためと考えられる．

このように砂州形状は河口地形の安定性を議論する上 て極めて重要な因子となっている.我力国の河口には大 規模な砂州か形成されることが多く，兴のため導流堤に よる河口維持の事例が多く見られる . しかし近年 , 河口 砂州力縮退し, 河口内に押し込まれている事例力潵見さ れる $\left(川\right.$ 村ら ${ }^{1)}$ ) .ここで得た知見は，他河川での河口 処理対策を検討する際に非常に有用であると考える.な お，河口地形の安定を長期に渡り維持するためには，一 時的な土砂投入ばかりてなく, 近年における沿岸漂砂量 の変化等も考慮しながら定期的なフォローが必要である と考えられる .

\section{6 ．結論}

本研究では, 鳴瀬川河口域における近年の地形変化が 波浪場に与える影響を明らかにするとともに，河道内侵 入要因およひ砂州形状か砂州の河道内侵入に与える影響 について検討を行った . 乥の結果 , 以下のことか明らか になった 。

・鳴瀬川河口部周辺は, 1996年頃まて安定した河口形 状を維持してきたが，近年侵食が進んできており， このため砂州前面の波高が高くなる環境となってい る.

・拡張型ブシネスク方程式を用いた地形変化シミュ レーションにより算定した河道内の土砂堆積量と実 測による堆積量との関係を調べた結果，両者は概ね 一致しており，越波により砂州の河道内侵入か泩じ たことが示された .

・越波による砂州の河道内侵入を防止するためには， 砂州高さのみならず砂州幅も重要な因子となってく ることが示された .
・ ここで示した手法は波浪による砂州地形変化を再現 していることから，他の現地河口部に対しても適用 性か高いと考えられ, 治水, 利水, 乥して環境上問 題となる砂州の河道内侵入対策を検討する際に有用 な知見を得ることができる．

謝辞 : 本研究を行うに際し，貴重な資料を提供頂いた国 土交通省東北地方整備局北上川下流河川事務所，並びに 宮城県石巻港湾事務所より各種資料を提供頂いた .ここ に記して厚く謝意を表する。

\section{参考文献}

1) 川村育男, 田中仁 : 中導流堤のある河口における砂州地形变 化特性，河川技術論文集，第10巻，pp.357-362, 2004.

2) 佐藤慎司，山本幸次，和田一範，伊澤武仁，大谷靖朗，橋本 新 : 大曲海岸におけるヘッドランド周辺の漂砂観測と海浜変 形予測，海岸工学論文集，第45巻, pp.556-560, 1998.

3) 望月倫也, 宇多高明, 大類光男, 大谷靖郎 : 仙台湾北部沿岸 の海浜変形の実態, 海岸工学論文集, 第37巻, pp.369-373, 1990 .

4) Wei, G. Kirby, J. T., Grilli, S. T. and Subramanya, R.: A fu11y non1inear Boussinesq mode1 for surface waves. Palrt1. Highly nonlinear unsteady waves, Journal of Fluid Mechanics, 1995.

5) Nwogu, O.: Alternative form of Boussinesq equations for nearshore wave propagation, Journal of Waterway, Port, Coastal, and Ocean Engineering, Vol.119, No6, pp.618-638, 1993.

6) 南將人, 真野明 : 人エリーフ開口部の地形変化計算の一考察 , 東北地域災害科学研究, 第40巻, pp.229-234, 2004.

7) 田中仁, 首藤伸夫 : 波・流れ共存時の底面摩察に関する研究, 海岸工学論文集 , 第27回 , pp.163-167, 1980.

8) 田中仁 : 波・流れ共存場における底面摩察係数の陽形式近似 式, 土木学会論文集, 第417号/II-13, pp.285-288, 1990.

(2006. 9. 30受付) 